Editorial - Editorial

\title{
Language and Content in Higher Education
}

Lenguaje y contenido en educación superior

Língua e conteúdo no ensino superior

Universidad de La Sabana, Chía, Colombia

Corresponding author: jermaine.mcdougald@unisabana.edu.co

Orcid: orcid.org/oooo-0002-2558-5178

\section{To reference this article / Para citar este artículo / Para citar este artigo:}

McDougald, J.S. (2017). Language and content in higher education. Latin American Journal of Content and Language Integrated Learning, 10(1), 9-16. doi:10.5294/laclil.2017.10.1.1 


\section{Introduction}

Language is a crucial element in not only the exchange of ideas but in collaboration and the construction of new knowledge. In the context of foreign or additional language learning, English has come to occupy an almost unique position as a leading global language; global English in a sociolinguistic context referring almost literally to the use of English as a global language (see papers in Cancino, Dam, \& Jæger, 20I I; Graddol, 2006; Hashim \& Leitner, 20I4). The effects of globalization are making the need to understand and use English increasingly more of a need than a mere desire - and no least in higher educational institutions (HEIs) worldwide. Indeed, "globalization and the Information Age have placed higher education at a crossroads .... Universities worldwide are clearly in a state of rapid change, the language landscapes are changing, and the stakes are high" (Marsh, Pavón Vázquez, \& Frigols Martín, 2013, pp. 9-10), with the demands for innovation in an international educational marketplace creating unprecedented competition. The many degree programs in non-majority English-speaking countries that are now delivered either completely or partially in English are clear evidence for this (Björkman, 20I I; Carloni, 20I3b; Wit, Hunter, Howard, \& Egron-Polak, 20I5).

Thus, the successful use of English in academic settings has become one of the greatest challenges for learners in higher education. As a result, it is no surprise that in many universities around the world are teaching English to students as a second, third, or foreign language. Yet the non-linguistic challenges of university learning-such as the use of higher order thinking skills, problem-solving skills, and professional communication skills, alongside the content-knowledge demands of degree programs-remain. It is critical that students, if they are to become bilingual professionals in their respective fields, be prepared to manage both language and content knowledge effectively. Moreover, an exclusive focus on language, even "academic language", too often ignores the need to apply this language through the use of twenty-first century skills (JaleniauskienL, 20I6).

The language courses offered by HEIs, supposedly to provide learners with the tools needed to meet these challenges, too often 
come up short. In many cases, English is taught separately, divorced from the communicative needs of students' content-oriented degree programs-or content courses are simply taught in English, with the expectation that students will somehow "magically" acquire the necessary professional communicative competences in the language. This is where problems arise: with the belief that the teaching of content and language are being integrated when, in fact, they are not. This challenge has led researchers and practitioners to explore innovative alternatives that truly integrate language and content in the formation of future professionals.

\section{Content and language learning in higher education}

Numerous pedagogical approaches and methodologies have sought to address both language and content in higher educational settings, including Content-Based Instruction (CBI) (Costa \& Coleman, 20IO; McDougald, 2007a), English-Mediated Instruction (EMI) (Corrales, Paba Rey, Lourdes, \& Escamilla, 20I6; Toh, 20I6), English for Academic Purposes (EAP) (Evans \& Morrison, 20I I; Tatzl, 20I I), Content and Language Integrated Learning (CLIL) (Carloni, 2013a; Chostelidou \& Griva, 20I4; Costa \& Coleman, 20I0; Fortanet-Gómez, 20I3). Such approaches have been used individually or through blends of two or more, such as initiatives to combine aspects of CLIL with English for Specific Purposes (ESP) (Ruiz-Garrido \& Gómez, 2009; Taillefer, 2013).

While there is debate over the nature and relationship of approaches that explicitly seek to integrate content and language learning, such as CLIL or CBI, in general these types of approaches are centered on the notion that students improve by not merely "learning" but "using" the target or vehicular language to meet immediate communication and learning needs-much as with a first language. However, if such approaches are to deliver on this promise in university settings, teaching faculty must not only themselves be prepared linguistically, and must not only have the knowledge and skills to teach their subject in the vehicular language, but also the knowledge and skills to support the development of learners' professional communicative competences in that language. 


\section{Conclusion}

Yet though debates on how to best to achieve the effective integration of content and language teaching have been going on for decades, it must be admitted that few firm conclusions and little consensus have been reached. Nevertheless, it has become a fact that English has increasingly become part of the lives of university students, faculty, and administrators worldwide-or needs to become so, at the risk of their being disadvantaged in an increasingly globalized economy and society. Regardless of the approach taken to addressing this issue, there are five key areas in which content and language educators must be conversant (McDougald, 2007b). These areas would provide all practitioners with a starting point to reflect on when considering how to approach language and content in the classroom.

I. Content area: educators must be well-versed in the particular content subject area that they teach.

2. Pedagogy: educators must be prepared to implement strategies that provide students with opportunities to access content in pedagogically valuable ways and employ a range of evaluation options to evaluate both content learning and language learning.

3. Second Language Acquisition (SLA): educators need to understand how learner language acquisition develops and evolves over time so as to facilitate the process.

4. Language Teaching: teachers need to know how to support the use and development of the the "four skills" (reading, writing, listening, and speaking) of language in their classes.

5. Materials selection and adaptation: educators must be able to select and, as necessary, adapt a variety of methods, approaches, instructional materials to meet the language/linguistic needs of their students.

Although there are others that are also relevant and necessary to consider, these five clearly cover the areas/aspects that are often excluded or not seriously considered when managing content and language. If considered and employed in an environment that caters to 
CLIL or CBI they serve as a basis for towards a successful integration of content and language in HEIs.

\section{In this issue}

The articles in this issue of the Latin American Journal of Content and Language Integrated Learning (LACLIL, Vol Io, No. I, 20I7) are all focused on the integration of content and language in HEIs. Perez \& Ferrer (20I7) explore the use of English with health sciences (medicine and dentistry) undergraduate programs in Colombia, choosing a self-reflection model encouraging learners to self-assess their learning progress. Keogh (20I7) examined the use of a smartphone-based instant messaging service (WhatsApp) on interactions within the group of learners, as well as how and student reflections support effective scaffolding, increased participation, and the creation of a learning community.

On different note, Kewara, (2017) considers the need to prepare teachers (in Thailand) to both content and language successfully, looking at ways to increase content teachers' confidence with using English as a medium of instruction and transform monolingual classrooms into integrated bilingual learning spaces. Similarly, Montoya and Salamanca (2017) look at the internationalization of a Colombian HEI's curriculum, with a focus on training content teachers in communicative competences in English and the use of a CLIL approach to design content activities through collective team work.

Finally, Bernal- Castañeda, (2017) analyzes the obstacles faced by adult learners in vocational training programs, as well as the growing motivational, personal, and affective difficulties encountered in the English-language classroom in Spain.

Overall, this issue of LACLIL presents five innovative contributions to the debate on how to most successfully integrate content and language in higher education - and if there is perhaps one thing that can be agreed in this debate, it is that there is no "secret recipe" for making this integration a reality, nor only one approach or method that can achieve it. We trust this issue's contributions provide fresh ideas and 
inspirations that will help the many CLIL-oriented initiative ongoing worldwide move closer to meeting their goals.

\section{References}

Bernal-Castañeda, S. (2017). Affective limitations in Second Language Acquisition by Spanish adult learners in Vocational Training Programs. Latin American Jorunal of Content \& Language Integrated Learning, IO(I), I33-I6o. http://dx.doi.org/I0.5294/laclil.20I7.IO.I.6

Björkman, B. (20I I). English as a lingua franca in higher education: Implications for EAp. Ibérica, 22, 79-I00.

Cancino, R., Dam, L., \& Jæger, K. (20II). Policies, Principles, Practices: New Directions in Foreign Language Education in the Era of Educational Globalization (R. Cancino, L. Dam, \& K. Jæger, Eds.) (Vol. I). Newcastle upon Tyne: Cambridge Scholars Publishing.

Carloni, G. (2013a). CLIL in higher education: A case study. In L. G. Chova, A. L. Martínez, \& I. C. Torres (Eds.), INTED20I3 proceedings: 7th International Technology, Education and Development Conference, March 4th-6th, 2013 - Valencia, Spain (pp. 4856-4866). València, Spain: International Association of Technology, Education and Development (IATED). Retrieved from http://www.europarl.europa.eu/thinktank/ en/document.html?reference=IPOL_STU(20I5)540370

Carloni, G. (2013b). CLIL in Higher Education: a Case Study. 7th International Technology, Education and Development Conference (Inted2013), 4856-4866.

Chostelidou, D., \& Griva, E. (20I4). Measuring the Effect of Implementing CLIL in Higher Education: An Experimental Research Project. Procedia - Social and Behavioral Sciences, II6, 2169-2I74. http://dx.doi. org/IO.IOI6/j.sbspro.20I4.0I.538

Corrales, K. A., Paba Rey, Lourdes, A., \& Escamilla, N. S. (2016). Is EMI enough? Perceptions from university professors and students. Latin American Journal of Content and Language Integrated Learning, 9(2), I7-36. http://dx.doi.org/doi:I0.5294/laclil.2016.9.2.6

Costa, F., \& Coleman, J. a. (2010). Integrating content and language in higher education in Italy: ongoing research. International CLIL Research Journal, I(3), I9-29. Retrieved from http://www.icrj.eu/I3-74I 
Evans, S., \& Morrison, B. (20II). Meeting the challenges of English-medium higher education: The first-year experience in Hong Kong. English for Specific Purposes, 30(3), I98-208. http://dx.doi.org/IO.IoI6/j. esp.2OII.OI.OOI

Fortanet-Gómez, I. (2OI3). CLIL in higher education: Towards a multilingual language policy. Bristol, England: Multilingual Matters.

Graddol, D. (2006). English next: Why global English may mean the end of "English as a foreign language." London, UK: The British Council. Retrieved from http://www.britishcouncil.org/learning-research-english-next.pdf

Hashim, A., \& Leitner, G. (20I4). English as a lingua franca in higher education in Malaysia. The Asian Journal of Applied Linguistics, I(I), I6-27. Retrieved from http://ssrn.com/abstract=24I8II6\%5Cnhttp://caes. hku.hk/ajal

JaleniauskienL, E. (20I6). Revitalizing Foreign Language Learning in Higher Education Using a PBL Curriculum. Procedia - Social and Behavioral Sciences, 232(April), 265-275. http://dx.doi.org/Io.IoI6/j.sbspro.20I6.IO.oI4

Keogh, C. (2017). Using WhatsApp to Create a Space of Language and Content for Students of International Relations. Latin American Jorunal of Content \& Language Integrated Learning., IO(I), 75-IO4. http://dx.doi. org/IO.5294/laclil.2017.IO.I.4

Kewara, P. (2017). Phrasebook: a way out for CLIL teachers in Thailand. Latin American Jorunal of Content \& Language Integrated Learning., IO(I), 49-73. http://dx.doi.org/IO.5294/laclil.2017.IO.I.3

Marsh, D., Pavón Vázquez, V., \& Frigols Martín, M. J. (2013). The higher education languages landscape: Ensuring quality in English language degree programmes. València, Spain: Valencian International University, Design and Multimedia Contents Department. Retrieved from https:// tempus-unico.eu/images/ELT_training_Cordoba/Ensuring-Quality -English-Degrees.pdf

McDougald, J. S. (2007a). Instrucción Basada en el Contenido (CBI) para un programa universitario: una preocupación pedagógica de La Universidad el Bosque (Master's thesis, Universidad El Bosque, Bogota, Colombia).

McDougald, J. S. (2007b). Instrucción Basada en el Contenido (CBI) para un programa universitario: Una preocupación pedagógica de la Universidad El Bosque (Master's thesis, Universidad El Bosque, Bogota, Colombia). 
Montoya, S. I., \& Salamanca, C. (2017). Uso del enfoque cLIL como estrategia de internacionalización del currículo en una Institución de Educación Superior colombiana. Latin American Jorunal of Content \& Language Integrated Learning, IO(I), IO5-I3I. http://dx.doi.org/IO.5294/ laclil.20I7.IO.I.5

Perez, Y., \& Ferrer, E. (2017). Exploring the Suitability of an English for Health Sciences Program: Model and Report of a Self-Evaluation Process. Latin American Jorunal of Content \& Language Integrated Learning, IO(I), I7-48. http://dx.doi.org/I0.5294/laclil.2017.IO.I.2

Ruiz-Garrido, M., \& Gómez, I. F. (2009). Needs analysis in a CLIL context: A transfer from ESP. In D. Marsh, P. Mehisto, D. Wolff, R. Aliaga, T. Asikainen, M. J. Frigols-Martin, ... G. Langé (Eds.), cLIL Practice: Perspectives from the field (pp. I79-I88). Jyväskylä, Finland: CLIL Cascade Network, University of Jyväskylä. Retrieved from http://scholar.google. com/scholar?hl=en\&btnG=Search\&q=intitle:Needs+Analysis+in+a+CLIL+Context+:+A+Transfer+from+ESP\#O

Taillefer, G. (2013). CLIL in higher education: the (perfect?) crossroads of ESP and didactic reflection. Multiplicités Des Approches En Anglais de Spécialité, 63(2013), I8. http://dx.doi.org/I0.4000/asp.3290

Tatzl, D. (20I I). English-medium masters' programmes at an Austrian university of applied sciences: Attitudes, experiences and challenges. Journal of English for Academic Purposes, Io(4), 252-270. http://dx.doi. org/Io.10i6/j.jeap.2011.08.003

Toh, G. (2016). Extrapolating from an Inquiry into Curricular Issues Concerning the Adoption of English as Medium of Instruction in a Japanese University Situation. Latin American Journal of Content \& Language Integrated Learning, 9(I), 210-235. http://dx.doi.org/I0.5294/ laclil.2016.8.1.9

Wit, H. de., Hunter, F., Howard, L., \& Egron-Polak, E. (20I5). Internationalisation of higher education. Brussels, Belgium: European Parliamant. http://dx.doi.org/I0.286I/444393 